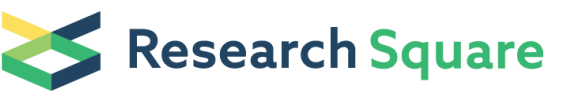

\section{Ethnobotanical Utilization of Kigelia africana (Lam.) Benth. according to Herbal Medicine Traders in Benin.}

Hubert Olivier Dossou-Yovo ( $\sim$ dohuoly@yahoo.fr)

Laboratory of Applied Ecology https://orcid.org/0000-0001-9913-6626

Fifanou G. Vodouhè

University of Parakou, Benin

Valentin Kindomihou

Laboratory of Applied Ecology, Faculty of Agronomic Sciences, University of Abomey-Calavi.

Brice Sinsin

Laboratory of Applied Ecology, Faculty of Agronomic Sciences, University of Abomey-Calavi, Benin.

\section{Research}

Keywords: Benin, Ethnobotanical, Infections, Kigelia africana, Medicinal Plants

Posted Date: August 17th, 2020

DOI: https://doi.org/10.21203/rs.3.rs-55498/v1

License: @ (i) This work is licensed under a Creative Commons Attribution 4.0 International License.

Read Full License 


\section{Abstract}

\section{Background}

This research aimed at gathering knowledge on the medicinal exploitation and magic utilization of Kigelia africana in Benin. The species has received very little attention in Benin where it is widely used in traditional medicine to treat diseases and recently recorded as a threatened species

\section{Methods}

A semi-structured questionnaire was used in different markets in Benin to gather ethnobotanical knowledge on Kigelia africana from herbal traders. Various percentages of traders were calculated, the Use Value of the most traded parts was determined and the two proportions test was performed to check for difference in Use Value.

\section{Results}

Thirty-six percent of respondents obtained parts of the species both by purchase in their own markets and by travelling far. The same proportion confirmed that they travelled very far before buying parts they used to sell. None mentioned harvesting the plant parts from wild populations. A high proportion of informants $(63 \%)$ reported selling fruits and bark whereas a relatively low proportion of them $(37 \%)$ sell fruits, bark and leaves of the species. Bark was recorded as most sold followed by fruits. Leaves were recorded as least sold.The majority of respondents confirmed the scarcity of the species in recent years. Thirteen diseases, disorders and rituals were recorded and the majority oftraders mentioned the use of bark in treating stomach infections followed by gynecological disorders. Fruits were mainly used in magic rituals followed by treatment for stomach infections. Fruits showed a Use Value higher than bark although bark was recorded as most in demand. Five types of preparation were recorded and $54 \%$ of traders mentioned bark decoctions while $27 \%$ highlighted infusion of fruits in water.

\section{Conclusions}

Kigelia africana plays an important role in local ethnomedicine and bark and fruits were the most traded organs. Its fruits were relatively more important than bark in terms of uses but harvesting and trade of its parts are threats to the species. Urgent conservation tools are needed for its long-term sustainable exploitation.

\section{Introduction}

Medicinal plants play an important role in people's lives and there is a great need to record the ethnobotanical knowledge that they hold on the medicinal and medico-magic exploitation of plant species. Cunningham [1] reported that 70 to $80 \%$ of the world population use plants for their primary healthcare. Furthermore, plant species harvested from wildpopulations serve as raw materials for commercial pharmaceutical factories and for local informal trade [2]. Medicinal plants are globally 
valuable sources of herbal products but many wild populations are under threat and are disappearing at a high speed [3]. The same authors stated that more than one-tenth of plant species are used in drugs and/or health products. Consequently, some authors argue that sustainable harvest is the most important conservation strategy for wild-harvested medicinal species given their contributions to local economies and their long term value to harvesters [4]. Medicinal plants have generally received more attentions in other parts of the world than in Africa. For instance, it has been reported by Chen et al. [3] that China and India have the highest numbers of medicinal plants used, with 11,146 and 7,500 species, respectively.

Despite the important historical and current use of medicinal plants by African populations, there has been relatively little research undertaken on medicinal plants in Africa, and, consequently, a lack relevant knowledge on the medicinal and magic utilization of plants species. For instance, van Andel et al. [5] reported that a desire to maintain cultural identity and a preference to treat ailments with herbal medicines are motivations for migrants to continue using medicinal plants from their home country after moving to Europe and the USA. Medicinal plants in Africa and other parts of the world are collected from a wide range of vegetation types. For example, people collect plants from sacred groves in India [6], and termitaria-related plant species are used for medicinal and medico-magic purposes in Benin [7]. Medicinal exploitation of mangrove plant species has recently been reported by Dossou-Yovo et al. [2]. Kigelia africana (Lam.) Benth, sausage tree, belonging to the Bignoniaceae botanical family, is a tree with a low branches, up to 10-12 (-20) $\mathrm{m}$ high which establishes in Sudanian and Guinean savannahs and in some semi deciduous forests, usually on well-drained soils [8]. In African folk medicine, the species is used to treat various illnesses [9]. Singh et al. [10] also reported the use of $K$. africana to treat skin diseases and other infections. In Zimbabwe, bark of the species is usedto relieve toothache [11]. Although $K$. africanahas recently been recorded among plant species used to treat women sterility in Benin [12], this species has received very little attention in Benin. In contrast, $K$. africana is widely used in traditional medicine to treat diabetes in Benin where it is recorded as a threatened species [13]. The aim of this research is to gather knowledge on the medicinal exploitation as well as the magic utilization of $K$. africana in Benin. This information will contribute to acknowledge $K$. africana with a perspective on its sustainable conservation.

\section{Materials And Methods}

Surveys were conducted in some of the cities with the highest population density in southern Benin, and with herbal medicine traders in six markets using a semi-structured questionnaire on the ethnobotanical utilizations of $K$. africana. The markets were Pahou, Zobê and Kpassê markets in Ouidah District, with population density of 445 inhabitants/sq km (Department of Atlantique), Cococodji market in AbomeyCalavi District, 1,010 inhabitants/sq km (Department of Atlantique), and Vêdoko and Dantokpa markets in CotonouDistrict with 8,595 inhabitants/sq km (Department of Littoral). Six traders were interviewed per market. Thirty-six herbal traders were surveyed because they sell medicinal plants and also provide advice on their use to many customers. Various percentages of traders who mentioned species parts and diseases were calculated using the formula 
Tobetter assess the diversity of ethnobotanical knowledge on $K$. africana held by traditional herbal traders, we also calculated the Use Value (UV) of most sold parts [14]. The Use Value is an index widely used to quantify the importance of useful plants. It combines the frequency with which a species is mentioned with the number of uses mentioned per species. In the framework of our study, the Use Value is the relative frequency of citation of a part as most sold and the number of diseases mentioned per part. We performed a two proportions test, using R 4.0 software, at 0.05 level of probability to check for difference in Use Value between organs.

\section{Results}

\section{Sources of Kigelia africana parts sold bymedicinal plants traders}

Table 1 shows that $36 \%$ of respondents confirmed that they purchase $K$. africana plant parts both in the markets where they sell them and after travelling far to make the purchases. Similarly, the same proportion of traders mentioned that they exclusively travel very far to buy the species parts they sell. The minimum distance travelled to obtain the material is 25 kilometers and traders visit both rural areas and other big markets. A relatively low proportion of traders mentioned that they obtained the plant parts only in the market where they sell them, and a very low proportion mentioned they obtained the plant parts in their markets and also from other nearby markets. It is important to highlight that no herbal trader reported collecting the species from the wild despite the proximity of some surveyed markets to old fallows and forests accessible to local populations.

\section{Ranking and availability of Kigelia africana parts sold by traders}

Herbal traders mainly sell the bark, fruits and leaves of $K$. africana. Bark of $K$. africana is locally called "Yamblikpogoto" in Fon and "Ekpakpahoundoror" in Yoruba. Its fruits are called "Anonkan" or sometimes "Yamblikpo sin atississin" in Fon. Fruits of K. africana are called "Kpahoundoror" in Yoruba. The tree itself is called "Yamblikpo" in Fon and "Iguikpahoundoror" in Yoruba. Table 2 reveals that a high proportion of informants reported that they sell only the fruits and bark whereas a relatively low proportion of them sell fruits, bark and leaves of $K$. africana.No trader sells only fruits, only bark or only leaves. Regarding the ranking of parts sold (Table 3), the majority of surveyed herbal traders mentioned bark of $K$. africana as most in demand followed by fruits. A very low proportion of traders confirmed bark and fruits as equally sold. Leaves of $K$. africana were recorded as the least sold part. The majority of traders (Table 4) highlighted that $K$. africana parts available for sale have become very scarce in recent years and a low proportion of themreported availability of the species throughout the year as well as availability during the rainy season.

\section{Diversity of diseases, disorders and rituals treated using the species parts according to traders}


A total of thirteen (13) diseases, disorders and magic rituals were recorded. Eight (8) diseases and disorders were mentioned by herbal traders as treated using bark whereas seven (7) diseases, disorders and magic rituals were treated using fruits. Leaves were only mentioned for use in magic rituals. Two medical conditions were reported commonly to be healed using bark or fruits, gynecological disorders and leg infections. In addition to these diseases, bark of K.africana serves to treat stomach infection, stomachache, anemia during women's menstrual periods, vomiting, cough and constipation. The greatest percentage of herbal traders $(72 \%)$ mentioned the use of bark to treat stomach infectionsfollowed by gynecological disorders (18\% of respondents). Regarding fruit utilization, apart from the two common diseases, treatment of hemorrhoids and obesity,stimulation of breast milk production, wound healing and magic rituals were all reported. The use in magic rituals is locally called "Vossissa" or "Vodounsakpata do ay" in Fonand people put fruits of K.africana onfirewood gathered in the field or bush to deter others from stealing it.Regarding the importance of fruit use, $27 \%$ of herbal traders mentioned the use of fruits in magic rituals followed by stomach infections reported by $18 \%$ of them.

The Use Value of most sold parts (Table 5) shows 0.875 for fruits whereas bark exhibits a Use value of 0.347. The two proportions test revealed a significant difference between the Use Value of fruits and bark $(p=0.03)$. Since none mentioned leaves as most sold part, its UV was not calculated.

\section{Diversity of preparation modes according to herbal traders}

In order to treat the diseases and disorders, and for ritual uses, five (5) types of preparation were reported by herbal traders, decoction, infusion in a traditional alcoholic drink locally called "Sodabr" in Fon, infusion in water, the direct use of the entire part, and its use as a powder. The first two modes are used for bark whereas the remaining modes as well as decoction are used for fruits. So, decoction was the only common preparation mode recorded for bark and fruits. Concerning leaves, they were mentioned as entirely used in rituals. With regards to the importance of each type of preparation, the greatest percentage of herbal traders (54\%) mentioned the use of bark as decoction while infusion of fruits in water was reported by $27 \%$ of respondents followed by decoctions and use of the entire plant in rituals ( $18 \%$ of informants for each). It is important to highlight that fruits are processed to powder and used to heal wounds, and this was mentioned by $9 \%$ of medicinal plant sellers surveyed.

\section{Discussion}

\section{Sources of Kigelia africana parts sold by herbal traders}

The majority of traders have to travel far and very far to buy the plant parts. Respondents highlighted a critical scarcity of the species in the last few decades. This was confirmed by the fact that none of them mentioned collecting the plant from wild populations. According to Chen et al. [3], medicinal plant resources are being harvested in increasing volumes, largely from wild populations. So, if $K$. africana was readily available in the wild, traders might be expected to collect its parts free of chargefor sale. Moreover, some surveyed markets are close to natural forests and old fallows. In addition, the low proportion of 
herbal traders who mentioned that they are exclusively provided with the species parts in their own markets is a real proof of scarcity.

\section{Ranking of Kigelia africana parts sold by traders}

The majority of traders used to sell fruits and bark of the species and in a relatively low proportion species fruits, bark and leaves. Kigelia africana parts are frequently demanded in markets and bark was reported as the most traded part followed by fruits. Bark collection is a threat to the species since indigenous people harvest it without regard to likely damage to the tree. Furthermore, harvesting of the fruits and leaves, and cutting down of flowers significantly reduce the reproductive capacity of the species. Vodouhè et al. [15] confirmed that non-timber forest species cannot be sustainably harvested in the absence of yield studies, harvesting adjustments and monitoring of regeneration. Some years ago, Gaoue and Ticktin [16] noticed a negative impact of bark and foliage harvest on the reproductive performance of Khaya senegalensis in Benin. Compared to practices in South Africa, bark is ranked third among the most frequently sold parts of a range of medicinal plants, after roots and bulbs [17]. Similarly to the present results, Dossou-Yovo et al. [7] pointed out bark as the most used part followed by leaves, when considering uses of medicinal termitary-related plants in northern Benin. The present results also confirm the work of Gaoue and Ticktin[16]who stated that bark of $K$. senegalensis plays a crucial role as medicine for indigenous people in Benin.

\section{Diversity of illnesses disorders treated, and rituals according to traders}

Thirteen (13) diseases, disorders and magic rituals were recorded in this study. This confirms that African populations hold relevant knowledge on medico-magic uses of plant species.In other words, the connection between Africanpopulations and the uses of medicinal plants to cure illnesses dates from the far past. Among 30 illnesses and disorders healed using 22 plant species recorded by Dossou-Yovo et al. [7], the present study revealed 13 illnesses and disorders cured, and rituals performed using parts of only one plant species like K.africana. That finding suggests the great importance of $K$. africana uses in the life of the local population. $K$. africana in African folk medicine but also in Indian traditional medicine shows convergence in the uses of that species parts and several diseases treated with it [9-11].

In addition to the relative frequency of citation of parts as most demanded and the diversity of diseases stated above, the Use Value (UV) of fruits and bark confirm the relative importance of each part as well as the diversity of indigenous knowledge on the species held by the traders and by traditional healers who purchase $K$. africana. Although fruits ranked second in demand, they exhibited the higher UV which proved that they were relatively more important than bark in terms of uses. In other words, fruits are generally less demanded than bark but indigenous people hold relatively more knowledge on its uses compared to bark. Barbosa et al. [18] suggested roots as the most used part when noticing that it was the most often sold part. Our results confirm the fact that the most sold part does not automatically mean the relatively more important in terms of uses.

\section{Diversity of preparation modes}


Five types of preparation were recorded in this study and this proves the diversity of medicinal and medico-magic knowledge that herbal traders have on K. africana. According to Yang and Ross [19], decoctions have the strongest action of all of the traditional types of preparation in China and need a reasonable amount of time to prepare. When investigating ethnopharmacological uses of 7 medicinal plants in Mali, Togola et al. [20] reported decoction of the leaves as the main form of preparation and leaf powder was mostly used for infusions. Similarly, the present study found decoctions as the predominant type of preparation, indicating the efficiency of decoctions in herbal medicine. Infusion of fruits, which ranked second in this study, corroborates findings of other authors who reported decoction and infusion as the most important forms. Jackson and Beckett [11], in their review article on $K$. africana, highlighted the use of bark decoction to relieve toothache in Zimbabwe as well as infusion made from the ground bark and fruits to cure illnesses.

\section{Conclusion}

Kigelia africana is widely used in herbal medicine in southern Benin. Parts of the species are used to treat a variety of illnesses and disorders and are exploited in magic rituals. Harvesting of plant parts from the wild threatens the survival of the tree and there is a need to undertake conservation of thespecies to allow its long-term sustainable exploitation.

\section{Declarations}

\section{. Ethics approval and consent to participate}

Not applicable.

\section{. Consent for publication}

Not applicable.

\section{. Availability of data and materials}

Please contact author for data requests.

\section{. Funding}

No funding

\section{. Competing interests}

The authors declare that they have no competing interests.

\section{. Authors' contributions}


Dossou-Yovo H. O. was the originator of the research. He wrote the first draft of the research proposal, participated in the data collection and analysis as well as manuscript writing and its submission.

Vodouhè F. G. participated in proposal writing, collaborated during data collection and contributed to analysis, manuscript writing and editing.

Kindomihou V. participated in the manuscript reading and editing.

Sinsin B., as head of the laboratory, he read, edited and commented on the manuscript for its improvement. He provided valuable comments that helped improve the quality of this manuscript.

\section{. Acknowledgments}

All authors are grateful to herbal medicine traders who participated in this research.

\section{References}

1. Cunnigham AB. African medicinal plants. Setting priorities at the interface between conservation and al primary healthcare. People and plants Working Paper 1. UNESCO, Paris. 1993.

2. Dossou-Yovo HO, Vodouhè FG, Sinsin B. Ethnobotanical survey of mangrove plant species used as medicine from Ouidah to Grand-Popo districts, Southern Benin. American Journal of Ethnomedicine.2017;4:1-6.

3. Chen S, Yu H, Luo H, Wu Q, Li C, Steinmetz A.Conservation and sustainable use of medicinal plants: problems, progress, and prospects. Chinese Medicine. 2016;11:37-46.

4. Schippmann U, Leaman DJ, Cunnigham ABA. Comparison of cultivation and wild collection of medicinal and aromatic plants under sustainability aspects. Bogers R. J., Craker L. E., Lange D. (eds). Medicinal and Aromatic Plants. 2006;75-95.

5. van Andel T, Fundiko MCC. The trade in African medicinal plants in Matonge-lxelles Brussels (Belgium).Economic Botany.2016;70(4):405-415.

6. Rampilla V, Mahammad KS. Ethno-medicinal plants in sacred groves in East Godavari District. Andhra Pradesh, India. European Journal of Medicinal Plants.2015;9:1-29.

7. Dossou-Yovo HO, Vodouhè FG, Sinsin B. Assessment of medicinal uses of plant species found on termitaria in the Pendjari Biosphere Reserve in Benin. Journal of Medicinal Plant Research. 2014;8:368377.

8. Arbonnier M. Trees, shrubs, and lianas of West African dry zones. 2004;573 p.

9. Agyare C, Obiri DD, Boakye YD, Osafo N. Anti-inflammatory and analgesic activities of african plants. In Kuete V. (ed). Medicinal Plant Research in Africa. Pharmacology and Chemistry. 2013;725-752. 
10. Singh A, Kumari S, Singh NK, Singh AK. Ethnopharmacology and pharmacology of Kigelia africana(Lam.) Benth.International Journal of Green Pharmacy. 2018;11:23-31.

11. Jackson S, Beckett K. Sausage tree Kigelia pinnata: An ethnobotanical and scientific review. The Journal of the American Botanical Council. 2012;94:48-59.

12. Houmenou V, Adjatin A, Tossou MG, Yedomonhan H, Dansi A, Gbenou J, Akoègninou A. Etude ethnobotanique des plantesutilisées dans le traitement de la stérilité féminine dans les départements de l'Ouémé et du Plateau au Sud-Bénin. International Journal of Biological and Chemical Sciences. 2017;11(4):1854-1871.

13. Lawin IF, Laleyê OAF, Agbani OP. Vulnerability and the endogenous strategies of conservation of the plants used in the treatment of diabetes in the townships of Glazoué and Savè in Benin Center. International Journal of Biological and Chemical Sciences. 2016;10(3):1069-1085.

14. Zenderland J, Hart R, Bussmann RW, Paniagua NY, Zambrana SS, Kikvidze Z, Kikodze D, Tchelidze D, Khutsishvili M, Batsatsashvili K. The use of "Use Value": Quantifying importance in Ethnobotany. Economic Botany. 2019;73:293-303.

15. Vodouhè FG, Dossou-Yovo HO, Chadaré FJ, Gélinas N,Assogbadjo AE, Coulibaly O. Valuing the potential of non-timber forest products in financial valuation of savannah formation in Sudanian Region. Universal Journal of Agricultural Research.2016;4(5):183-197.

16. Gaoue OG, Ticktin T. Impacts of bark and foliage harvest on Khayasenegalensis (Meliaceae) reproductive performance in Benin. Journal of Applied Ecology.2007;45(1):34-40.

17. Rasethe MT, Semenya SS, Mayori A. Medicinal plants traded in informal herbal medicine markets of the Limpopo Province, South Africa. Evidence-Based Complementary and Alternative Medicine. 2019;11p

18. Barbosa F, Hlashwayo D, Sevastyanov V, Chichava V, Mataveia A, Boane E, Cala A. Medicinal plants sold for treatment of bacterial and parasitic diseases in humans in Maputo city markets, Mozambique. BMC Complementary Medicine and Therapies. 2020;20(1):19-31.

19. Yang Y, Ross J. Chinese Herbal formulas: Treatments principles and composition strategies. 2010;464p.

20. Togola A, Diallo D, Dembélé S, Barsett H, Paulsen BS. . Ethnopharmacological survey of different uses of seven medicinal plants from Mali (West Africa) in the regions Doila, Kolobani and Siby. Journal of Ethnobiology and Ethnomedicine. 2005;1(1):1-9.

\section{Tables}


Table 1 showing the proportion of traders according to source of $K$. africana parts.

$\begin{array}{llll}\text { Sources of } K \text { africanaparts } & \text { In their market and } & \text { Only travelling very for } & \text { Exclusively in their } \\ \text { purchase } & \text { travelling far } & \text { market } & \text { In their market and }\end{array}$
purchase travelling far market

nearby market

Percentage of
respondentsmentioning (\%)

Table 2 highlighting the proportion of traders according to parts sold.

Parts sold

Table 3 showing the ranking of most sold parts of $K$ africana

$\begin{array}{llll}\text { Parts mentioned as most sold } & \text { Bark } & \text { Fruits } & \text { Barkequal to fruits }\end{array}$

Table 4 showing traders' perception of parts availability in recent years.

\begin{tabular}{|c|c|c|c|}
\hline Traders' perception & Parts veryscarce & $\begin{array}{l}\text { Parts available throughout } \\
\text { the year }\end{array}$ & $\begin{array}{r}\text { Parts available in rainy } \\
\text { season }\end{array}$ \\
\hline
\end{tabular}

Percentage of traders (\%)

64

18

18

Table 5 stating the relative importance of most sold parts based on their Use Value (UV).

$\begin{array}{llll}\text { Ranking of most sold part } & \text { Bark } & \text { Fruits } & \text { Leaves }\end{array}$


0.347 